\title{
AN ANALYSIS OF STUDENTS' ABILITY IN DISTINGUISHING LEXICAL AND STRUCTURAL AMBIGUITY IN ENGLISH SENTENCES AT SECOND GRADE OF SMAN 1 LABUAPI IN THE ACADEMIC YEAR 2016/2017 \\ ${ }^{(1)}$ Irwandi ${ }^{(2)}$ Yuli Ismiati
}

${ }^{(1)}$ Lecturer of English Department Muhammadiyah University of Mataram

${ }^{(2)}$ Students of English Department Muhammadiyah University of Mataram

\begin{abstract}
Ambiguity is the property of having two or more distinct meanings or interpretations. Sometimes we found many ambiguities sentences when we are reading or listen to the English sentences. A word or sentence is ambiguous if it can be interpreted in more than one way. The problem stated in this study is: How is the students' ability in distinguishing lexical and structural ambiguity in English sentences? The purpose of this study is to investigate the students' ability in distinguishing lexical and structural ambiguity in English sentences at second grade of SMAN 1 Labuapi in academic year 2016/2017. This study used descriptive qualitative approach. The writer used purposive sampling for taking sample, namely class IPA 2 which consists of 22 students. The data were collected by gap filling test for lexical ambiguity word class of noun and label for structural ambiguity. The results of the research demonstrate that the students of SMAN 1 Labuapi were categorized into a very poor with average score was 4.450 .The writer illustrate the analysis result in the percentage of all test's items in simple sentences, there were 890 ambiguous word and phrase. Lexical ambiguity involve noun (150) and structural ambiguity involve noun phrase (30).Finally, based on the research findings, the writer concluded that more than a half of students at the second grade of SMAN 1 Labuapi had very poor ability in distinguishing lexical and structural ambiguity in English sentences.
\end{abstract}

\section{Key words: Lexical ambiguity, Structural ambiguity.}

\section{Introduction}

Language is communication instrument which need of people for interaction with other person, it is oral and written language. The language also has a meaning even we make conversation with other person it is misunderstanding, and we learn the meaning itself in semantic.

"Semantic is the technical term used to refer to the study of meaning (Palmer 1976:1)" so semantic have technical to find the meaning in language. Sometimes people do not get what we said to them. It is not because they do not hear it or something. However, occasionally we say a sentence which has more than one meaning. As a result, the listeners will have some different interpretations and this will make confusion for the listener. In this case, this misunderstanding is called an ambiguity. We can find ambiguous sentences everywhere, not only when people say something to us or spoken but we can also find it in written forms, like in the book, newspaper, magazine, and so on. This ambiguity can happen if there is more than one meaning which can be interpreted by the people who read or listen to the ambiguous 
sentences or phrases. This ambiguous expression can happen in one word or one phrase in sentence especially in lexical and structural ambiguity.

Ullmann (1972:156) divides ambiguity into three kinds; Phonetic, grammatical and lexical. But the writer just uses structural and lexical as the subject of analysis, because the structural and lexical ambiguity often we met in daily conversation or event we read the book.

\section{METHOD}

The research design of this study is descriptive qualitative. This study would describe the ability of second grade students of SMAN 1 Labuapi in distinguishing lexical word class of noun and structural ambiguity by labeled sentences/ phrases in English simple sentences.

According to Sugiyono (2014:117), Population is a general object or subject that has specific quality and characteristic decided by the writer to explore and then elaborate a conclusion. The population of the study is the second grade students of SMAN 1 Labuapi in academic year 2016-2017 which consists of 61 students. They are distributed into three classes (IPA I, IPA II, IPS). So the writer uses purposive sampling for taking sample. By purposive sampling the writer took 1 class namely class IPAII with number of students 22 from all classes at the second year.

In collection the data, the writer use writing test especially gap filling for lexical word class of noun. But in structural ambiguity the writer use labeled way in English simple sentences. The writer took the data by applying the following steps:

In this research the writer use writing test is gap filling for lexical word class of noun which consists of 10 items. But in structural ambiguity the writer use label way in sentences/phrases which consist of 10 items in English simple sentences. Because this way is more affective to describe clearly how are put together as combinations of phrases. In turn, are combinations of words and show the correct meaning about sentence/ phrases is containing ambiguity in English simple sentences. The writer organized the position of the students' seat before distributing the test in order they will not disturb one another and then the writer explained the direction of doing the test.

\section{FINDINGS AND DISCUSSION Findings}

Based on the research design and data collection in this research the writer used descriptive qualitative which aims at describing student's ability in distinguishing lexical and structural ambiguity in sentences. The data collection was taken from student's written test. Analysis data finding in this research goes through some steps, namely:

1) A test to measure the student's ability in distinguishing lexical and structural ambiguity in sentences and the total of items test 20 questions had been conducted at second grade students SMAN 1 Labuapi.

2) Descriptive analysis was conducted to know the basic features of data in this study, the data was described based on the mean score (average score) the finding can be explained as follow: 
a. Analysis of students' ability in lexical ambiguity especially word class of noun in simple sentence. There are 150 lexical word class of noun occurring in the students' answer sheets.

b. Analyzing structural ambiguity using labeled in sentences/phrases.

\section{Discussion}

Based on the results of data analysis, it shows that at second grades tudents of SMAN 1Labuapi had very poor ability in distinguishing lexical and structural ambiguity in English sentences. According Hurford and Heasley (1983: 128) explain that Lexical ambiguity is resulting from the ambiguity of a word. Lexical ambiguity is caused by homonymy and polysemy. Meanwhile Structural ambiguity happens because its words relate to each other in different ways, even though none of the individual words are ambiguous. So in this study the writer found more than a half of the students could not distinguishing lexical and structural ambiguity in English sentence. The finding was indicated by the results that all test's items in simple sentences there are 890 ambiguous word and phrase. They are 150 case of lexical ambiguity and 30 case of structural ambiguity. Structural ambiguity which is functioned as noun phrase is the most dominant found in simple sentences. Because structural ambiguity is the most dominant, it shows that the students had mistake analysis used by labeled. Consequently, they could not differentiate structures that make a sentence ambiguous. Besides that ambiguity occur in one word or one sentence in lexical the students difficult to understand the meaning of word. In doing analysis the student could not classify the class of word based on parts of speech categories. Finally the students had very poor ability in distinguishing lexical and structural ambiguity. Based on the data above, it can be concluded that the students have poor knowledge about the exact meaning of the word.

\section{CONCLUSION AND SUGGESTION}

\section{Conclusion}

Related with the explanation from the chapter before, it can be concluded that the students ability in distinguishing lexical and structural ambiguity in English sentences was very poor with average score 4.450 . The finding is indicated by the results that all test items of lexical ambiguity which presents involve noun 150while structural ambiguity presents involve noun phrase 30. Whereas, Structural ambiguity represent involve noun phrase 30. Structural ambiguity which is functioned as noun phrase is mostly found in simple sentences. Because structural ambiguity is the most dominant, it shows that the students had mistake analysis by using label.

\section{Suggestion}

Based on result of the research, the writer would like to give some suggestion for the English teachers, students, and the next researcher.

1. For the English teacher of SMAN 1 Labuapi 
a. The English teacher should be able to diagnose the student's difficulties in learning English especially in distinguishing lexical and structural ambiguity.

b. The teacher should give more exercises about lexical and structural ambiguity especially in part of speech and class of word.

2. For the Students.

a. The students should increase their understanding about the meaning of word class and improve their vocabulary

b. the students should pay more attention when the English teacher deliver an instruction in the classroom

c. The students must be given a specific attention effectively toward the teaching of English.

\section{BIBLIOGRAPHY}

Cruse, D. Alan. 2000. Meaning in language: An introduction to semantics and pragmatics. New York: Oxford University Press. 424 pages. (Review by Huttar 2001.)

Crystal, David 1980. A First Dictionary of Linguistic and Phonetic. Cambridge: University press.

Yule, George. 2006. The Study of Language: third edition: Cambridge University Press.

Djajasudarma, Fatimah. 1990. Semantik I: Pengantar ke Arah Ilmu Makna. Bandung: PT Refika Aditama

Purwaningsih Diah. 2014. An Analysis of Lexical and Structural Ambiguity Rubric Opini in Jawa Post. Unpublished Research Paper, Surabaya: University Surabaya.

Fromkin, Victoria, Rodman Robert, Hyams Nina,2006. An Introduction to Language. Nelson: University of California, Los Angeles.

Tambunan Andriani. 2009. The Analysis Of Lexical And Structural Ambiguity In Your Letter Jakarta Post. Unpublished Research Paper. University Of Sumatera Utara.

Hurford, James and Brendan Hesley.1983.Semantic: A Course Book. Cambridge: University press

Leech, Geoffrey 1981. Semantic the study of meaning. London: Penguin Books Longman (2nd edition, 2007)

Palmer, F, R.1976. Semantic: A New outline. London, Cambridge University Press.

Ullman, Stephen 1977. Semantics: An Introduction to the Science of Introduction Oxford. Brazil Brazil Blach well: Oxford University.

Sugiono. (2014) Metode Penelitian Pendidikan (Pendekatan kuantitatif,kualitatif dan $R \& D)$, Bandung: CV. Alfabeta.

Yule, George. 1985. The Study of Language. Cambridge: Cambridge University Press 